\title{
Applying embodied cognition approaches to L2 learning
}

\author{
Hideki Hamamoto \\ Kindai University, Osaka, Japan \\ hidekihamamoto@intl.kindai.ac.jp
}

\begin{abstract}
The longstanding view of the predominant linguistic paradigms is that linguistic representation is symbolic and independent of human bodily experiences. Opposed to this disembodied cognition view, recent empirical evidence from cognitive science suggests that human language cognition is grounded in embodied experiences. This embodied cognition view rests on the idea that the mind and the body are not separate entities and we are likely to understand partially some abstract linguistic concepts by relating them cognitively to our own bodily experience. This view suggests that $\mathrm{L} 2$ knowledge is also partially based on embodiment. Speakers of an L2 without embodied experiences may be called ' $L 2$ zombies' since they lack this authentic sensation. This paper reports on the efficacy of introducing the embodiment view into L2 learning such as in the teaching of the space-related adjectives 'high' and 'tall,' and the present perfect progressive construction. The findings indicate that due consideration of embodied experience is desirable to foster learners' true understanding of their L2.
\end{abstract}

Keywords: cognition, embodied experience, present perfect progressive tense

\section{1 - Introduction}

Recently, many researchers have advocated that linguistic concepts are based on bodily experiences, or embodiment (e.g., Gibbs, 2005; Langacker, 1987; Radden \& Dirven, 2007; Taylor, 2002; Tyler, 2012; Pecher \& Zwaan, 2005). They have proposed that language competence is a product of our general cognition. In other words, language is grounded in our cognitive experiences with the world. The term 'cognition' comes from psychology and refers to (i) human perceptual abilities of the external world, (ii) conceptualization, (iii) memory, and (iv) thinking and judgment. Cognition embraces all the mental activities under the control of the conscious mind and commonly includes subconscious mental activities with regards to linguistic competence. The word 
HAMAMOTO, Hideki - Applying embodied cognition approaches to L2 learning. Para lá da tarefa: implicar os estudantes na aprendizagem de línguas estrangeiras no ensino superior. Porto: FLUP, 2019, pp. 167-183 DOI: https://doi.org/10.21747/9789898969217/paraa9

'embodiment' refers to the involvement of our body in cognitive activity. Consider the excerpt from Gibbs (2005):

Many aspects of cognition are grounded in embodiment, especially in terms of phenomenological experience of our bodies in action. Embodiment may not provide single foundation for all thought and language, but it is an essential part of the perceptual and cognitive processes by which we make sense of our experiences in the world. (Gibbs, 2005, p.3)

This present research assumes the embodied cognitive view of language as a theoretical model. There is compelling evidence that symbols can be grounded in our experiences (Pecher \& Zwaan, 2005). However, as the excerpt indicates, embodiment may not be the single foundation for all thought and language.

The organization of this paper is as follows. The remainder of this section discusses some foundational assumptions of cognitive embodiment thesis and its key concepts. In relation to these concepts, to elaborate on the necessity of activation of perceptual representations in language processing, a hypothesis is proposed. This 'the second language zombie hypothesis,' which borrows the term from philosophy of mind (Chalmers, 1996), summarizes common problems of second language learners. Section two discusses two attempts which consider embodied experiences for teaching abstract linguistic issues: (i) synonymous and supplementary senses of the adjectives 'high' and 'tall,' (ii) the correct usage of the English present perfect progressive tense. Section three is dedicated to a general discussion on implications gained through these experiments and on how we can utilize our linguistic perspective successfully into L2 instruction. Section four concludes with discussing some remaining but important issues.

\section{1 - What are embodied cognitive experiences?}

Our basic assumption is that language, at least partly, is a product which results from our cognitions of bodily experience. As Gibbs (2005) says people's subjective, felt experiences of their bodies provide part of the fundamental grounding for language. He also says that our body serves as a significant resource for people's understanding of many abstract concepts. For example, the phrase 'look down on somebody' meaning 'despise' is based on our experience of our bodily action. When somebody despises another, he is most likely to take a stance of looking down on the person. In this manner, many expressions are motivated by our bodily action. In fact, there is a lot of evidence which supports this view. Consider the following: 
HAMAMOTO, Hideki - Applying embodied cognition approaches to L2 learning. Para lá da tarefa: implicar os estudantes na aprendizagem de línguas estrangeiras no ensino superior. Porto: FLUP, 2019, pp. 167-183 DOI: https://doi.org/10.21747/9789898969217/paraa9

(i) Human infants progressively build more complex mental understanding as they make kinesthetic sense of their physical experiences. Over the course of childhood, language develops in conjunction with perceptual symbols. (Smith \& Gasser, 2005)

(ii) When people are exposed to action verbs such as 'kick' or 'pick,' their motor regions are also activated. (Hauk, Johnsrude, \& Pulvermüller, 2004)

(iii) Some researchers propose that language processing facilitates movement and movement facilitates language comprehension. In other words, these two tasks cooperate bi-directionally. (Gibbs, 2005)

(iv) There is an experimental research which supports that perceptual symbols are routinely activated in language comprehension. (Zwaan, Stanfield, \& Yaxley, 2002)

These are examples of research to support the linkage between cognitive embodiment and language processing, to name but a few. This cursory review may attest to the fact that language is grounded on embodied experiences. Is this true for second language? We will see.

\section{2 - Second language zombie hypothesis}

Students often learn in ways which are disconnected to their experience, none more so than second language learning. The cognitive view of language that language is grounded in embodied experiences brings us a surprising hypothesis. That is the 'second language zombie hypothesis.' The term 'zombie' comes from the philosophy of mind. A philosophical zombie in the philosophy of mind is a hypothetical being that from the outside is indistinguishable from a normal human being but lacks conscious experience, qualia, or sentience (Chalmers, 1996). We sometimes observe a case where speakers of a foreign language who apparently use the language fluently actually lack conscious experience or real sentience of words. They speak a second language using the linguistic knowledge acquired indirectly from a grammar book or dictionary. They do not experience the authentic sensation which comes with a word. This situation can be called a second language zombie situation. Learners of a second language usually learn grammar rules (ex. those of subjunctive, or present perfect progressive tense) without developing a true understanding of them that native speakers of the language have acquired through embodied experiences. Learners practice applying the rules that they learn to problems in class, but they do not experience a feel for them. A full understanding 
HAMAMOTO, Hideki - Applying embodied cognition approaches to L2 learning. Para lá da tarefa: implicar os estudantes na aprendizagem de línguas estrangeiras no ensino superior. Porto: FLUP, 2019, pp. 167-183 DOI: https://doi.org/10.21747/9789898969217/paraa9

of a grammar rule derives from a perceptual simulation of it in their mind. Therefore, when we think of an authentic understanding of a second language, we emphasize the importance of embodied experiences. In the next section we will consider how we can develop a perceptual simulation of a concept through embodied experiences.

\section{2 - Two experiments}

We have two research questions. The first question is on whether an embodiment approach is applicable to teaching and learning English vocabulary or grammar. Grammar here means linguistic rules which cover syntactic, semantic, and phonological aspects of a language. The second question is how we can render cognitive embodied experience learnable and accessible to learners. To respond to these questions, two experiments were conducted.

\section{1 - Synonymous and complementary adjectives: high and tall}

Taylor (1992) says that 'tall' and 'high' are synonymous and complementary. The same word can be modified by both 'high' and 'tall' (ex. 'The tower is high/tall'). However, there are certain groups of words which are exclusively modified by either 'tall' or 'high' (cf. the wall is high/*tall; the boy is tall/*high). There must be a set of conditions or rules that regulate which objects may come with 'high' or 'tall' or can be modified by both. However, since the rules are not visible to learners, the distinction between 'high' and 'tall' constitutes a big barrier getting in the way of learning. Furthermore, many languages have only one word corresponding to English high and tall, as exemplified by Portuguese 'alto,' Polish 'wysoki,' and Japanese 'takai.' When Japanese refer to a tall building, they say 'takai tatemono (= tall building).' Also, when they refer to a high mountain they say 'takai yama (= high mountain).' The Japanese language does not have a distinction between 'tall' and 'high.' Therefore, Japanese learners of English often get confused in choosing 'high' or 'tall' to describe something which stands out in its vertical length. The knowledge they have acquired from a dictionary does not tell them exactly how they should choose 'high' or 'tall.' Japanese learners of English, who use 'tall' or 'high' according to the knowledge based on a dictionary, do not understand the real sentience. In this respect, they are zombie speakers of English as far as 'high' or 'tall' are concerned. The above discussion reminds us of the important concept 'quale' (pl. qualia). When we see something red, we receive a sensation of redness, when we drink bitter coffee, we receive a sensation of bitterness. Qualia or sensations are ones that are accessible to us introspectively and that together make up the phenomenal character of the 
HAMAMOTO, Hideki - Applying embodied cognition approaches to L2 learning. Para lá da tarefa: implicar os estudantes na aprendizagem de línguas estrangeiras no ensino superior. Porto: FLUP, 2019, pp. 167-183 DOI: https://doi.org/10.21747/9789898969217/paraa9

experience. Space-related adjectives like 'high' and 'tall' are related to qualia since the meanings of these adjectives are the sensations we perceive when we see something vertically prominent. The sensations or qualia are the meanings of these adjectives. Qualia are ineffable, or something we can't describe with words. Therefore, true, authentic meanings of these adjectives are only learnable through our own experience.

\subsection{1 - Procedure of experiment 1}

Experiment 1 consists of six steps, which starts with a questionnaire and ends with a T- test:

(i) a questionnaire to collect data for clarifying the rules by which English speakers select either high or tall

(ii) a cluster analysis based on the similarity of items to classify them into clusters

(iii) a factor analysis to abstract factors

(iv) a computational model to explain the process of selection

(v) an embodied cognitive method for teaching the meanings of the adjectives

(vi) a T- test to measure its effectiveness

The steps from (i) to (iv) are all preliminaries before the experiment. Our final goal is, of course, to attest the effect of the cognitive embodiment approach which may lead our learners to the authentic understanding of these adjectives.

\subsection{2 - The questionnaire}

A questionnaire was conducted to ask 34 native speakers of English about their preference of 'tall' and 'high' when they modify 41 objects using a rating scale. ${ }^{1}$ The scale consists of seven ratings: 1 (very good), 2 (good), 3 (less good), 4 (doubtful), 5 (bad), 6 (very bad), 7 (extremely bad). The table in the appendix is the result of the questionnaire. For each combination of the adjectives and the items, the smaller the average score is, the more preferred the combination is. For example, the first item in the table 'girl' gets a score of 1.12 for 'tall' and 6.09 for 'high,' which means that 'tall' is exclusively used but 'high' is not used for modification of 'girl.' As for 'bridge,' 'wall,' 'hill,' and 'precipice,' the preference of 'high' is much stronger than that of 'tall.' For modifying 'tower,' both 'tall' and 'high' can be used. On the other hand, there are some objects which cannot be modified by either 'tall' or 'high.' These items are 'room" and 'hair.'

\footnotetext{
${ }^{1}$ The questionnaire was conducted in 2007. The participants are 15 Americans, 6 Australians, 6 Canadians, 5 British people, and 2 New Zealanders.
} 
HAMAMOTO, Hideki - Applying embodied cognition approaches to L2 learning. Para lá da tarefa: implicar os estudantes na aprendizagem de línguas estrangeiras no ensino superior.

Porto: FLUP, 2019, pp. 167-183 DOI: https://doi.org/10.21747/9789898969217/paraa9

\subsection{3 - The cluster analysis}

A hierarchical cluster analysis using Ward's method cluster analysis was conducted to classify 41 items into groups in terms of compatibility with these adjectives. Members of each group have some features in common. As the result, the items are grouped into six clusters:

cluster 1 (modified exclusively by 'tall,' e.g., girl, glass, giraffe, fir tree, cocktailglass, skyscraper), cluster 2 (modified mainly 'tall' but sometimes 'high,' e.g., building, spire, pyramid),

cluster 3 (modified by both 'tall' and 'high,' e.g., grass, tower), cluster 4 (modified mainly by 'high' but sometimes 'tall,' e.g., mountain, bridge), cluster 5 (modified exclusively by 'high,' e.g., wall, ceiling, dome) cluster 6 (modified by none of these, e.g., room, hair)

\subsection{4 - The factor analysis}

A principal factor analysis using the Promax rotation was conducted to calculate a factor loading matrix and fishbone diagrams. The results of the analysis are illustrated in the following table (note that not all items are presented for the sake of simplicity).

\begin{tabular}{|l|l|l|l|}
\hline item & first factor load & item & second factor load \\
\hline hill & .79 & fir tree & .65 \\
\hline wall & .68 & pillar & .55 \\
\hline tunnel & .66 & girl & .51 \\
\hline bridge & .61 & pyramid & .22 \\
\hline cave & .59 & giraffe & .18 \\
\hline ceiling & .57 & bridge & .16 \\
\hline pillar & .55 & tunnel & .11 \\
\hline mountain & .48 & wall & .10 \\
\hline pyramid & .47 & tower & .06 \\
\hline tower & .21 & cave & .05 \\
\hline fir tree & .14 & hill & .01 \\
\hline giraffe & .07 & mountain & -0.04 \\
\hline girl & -0.19 & ceiling & -0.18 \\
\hline
\end{tabular}

Table 1. Factor loading matrix after Promax rotation

Considering a possible interpretation for the first factor, we notice that the shapes of higher-ranking objects in the first factor load column are cases of bad Gestalt, while the shapes of lower- ranking objects are cases of good Gestalt. Gestalt here means a unified or meaningful whole. Therefore, we can name the first factor as 'Gestalt feature.' As for the second factor, we notice that those objects ranked higher in the second factor column 
HAMAMOTO, Hideki - Applying embodied cognition approaches to L2 learning. Para lá da tarefa: implicar os estudantes na aprendizagem de línguas estrangeiras no ensino superior.

Porto: FLUP, 2019, pp. 167-183

DOI: https://doi.org/10.21747/9789898969217/paraa9

tend to be shaped like a rectangle with the longer sides being vertical. Those lowerranking objects satisfy this characteristic to a lesser extent. Therefore, we name the second factor as 'vertical prominence.' We can also notice that objects which are lowerranked in the first factor column and higher-ranked in the second factor column (e.g., wall, cave, hill, ceiling, mountain etc.) seem to have a common feature. When we look at those objects, we tend to focus on the top rather than look at the whole body. This cofactor, not exactly separated from the first and second factors, can be identified as the other factor and named as 'focus-on-top feature'. Therefore, three factors are identified: Gestalt feature (F1), vertical prominence (F2), and focus-on-top feature (F3). With these three conditions available, what we should do next is to clarify the relation between high/tall and these three factors in terms of a correlation matrix.

\subsection{5 - The correlation matrix}

Considering these three factors and preference ratings of adjectives, we can claim that the more compatible with F1, F2 and the less compatible with F3 an object is, the more likely it is to be modified by 'tall'. Reversely symmetrical is the case for 'high.' However, this is a rough illustration of the problem. What we need is the correlation matrix between these three conditions and two adjectives, which is analogous to what lurks in English native speakers' mind. The correlation matrix takes perceived information as input and returns the choice of high or tall as output. We have already obtained preference of 'high' or 'tall' of each item (appendix A). Therefore, we need to formulate perceived information of each object so that we may be able to calculate the correlation coefficients. In search of the correlation between three factors and each object, the author asked two informants (British and Canadian) to judge the degree of relevance between each of 41 objects and these three factors. Some examples of their judgment are: wall $=[F 1: L, F 2: L, F 3: H]$; fir tree, girl, glass $=[F 1: H, F 2: H, F 3: L]$; tower $=[F 1: H$, F2: H, F3: M]; pyramid = [F1:M, F2: H, F3: M]; mountain= [F1: M, F2: M, F3: H]. In this matrix, $\mathrm{H}$ stands for highly relevance, $\mathrm{L}$ means low relevance. $\mathrm{M}$ comes between $\mathrm{H}$ and L. If you see a girl, the perceived information of this object is represented as [F1: H, F2: $\mathrm{H}, \mathrm{F3}$ : L], which works as INPUT for the selection process of high/tall. Now that we have obtained both input and output information involved in the selection process of high and tall, we can calculate the missing part, i.e., the correlation coefficients. The result of the calculation is very simple, shown as Table 2 below. ${ }^{2}$

\footnotetext{
${ }^{2}$ For more details of this calculation, consult Ch. 3 of Klier \& Folger (1993).
} 
HAMAMOTO, Hideki - Applying embodied cognition approaches to L2 learning. Para lá da tarefa: implicar os estudantes na aprendizagem de línguas estrangeiras no ensino superior.

Porto: FLUP, 2019, pp. 167-183 DOI: https://doi.org/10.21747/9789898969217/paraa9

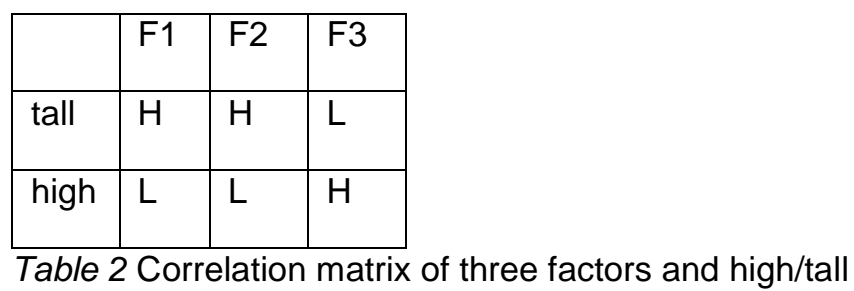

This matrix shows that 'tall' is highly relevant to F1 and F2 but low to F3, and that 'high' is low relevant to F1 and F2 but highly relevant to F3. This matrix is supposedly close to the content of embodied experience which English speakers may conceive when they observe something tall or high. Employing the technique of composition of relations, we can present a model of mental calculation of selection of 'high' or 'tall.' Assuming that objects like girl, tree, and glass are defined $[\mathrm{H}, \mathrm{H}, \mathrm{L}]$ in terms of three factors, the composition of relations is calculated as $[\mathrm{H}, \mathrm{H}, \mathrm{L}] \times[$ correlation matrix table 2] $=[\mathrm{H}, \mathrm{L}]$. The result shows that these objects are exclusively modified by 'tall.' In the same way, objects like mountain, wall, and hill are defined as [L, L, H]. The calculation returns $[L, H]$, which means that these objects are exclusively modified by 'high.'

\subsection{6 - Gestures}

After a series of preliminary steps, we are now ready for the experiment. Two adjectives 'high' and 'tall' are related to sensations or qualia when people experience something tall or high. Qualia are what people conceive through their own experience; therefore, they are not representational. The composition of relations, using the correlational matrix, is a theoretical model for the mental operation conducted in human brain for selection of adjectives. The important point is that the mathematical method here is a mere approximation of sense data processing. If the meanings of adjectives are qualia, they can be learned only through direct experience. Teaching technical details about the correlation matrix and the calculation is far from true cognitive experience. How can we convey meanings of these adjectives to learners? A possible way is to teach them through gestures which can give embodied cognitive experience. We must recall the correlation matrix which tells us that 'tall' is strongly relevant to good Gestalt, and vertical prominence, but low relevant to the focus- on- top feature, while 'high' is strongly relevant to the focus-on-top feature, but low relevant to first two conditions. Therefore, the gestures should be designed to take over those properties. Consider the following two sets of gestures. 
HAMAMOTO, Hideki - Applying embodied cognition approaches to L2 learning. Para lá da tarefa: implicar os estudantes na aprendizagem de línguas estrangeiras no ensino superior.

Porto: FLUP, 2019, pp. 167-183 DOI: https://doi.org/10.21747/9789898969217/paraa9

(i) looking at the figure (chanting the phrase: we can see the whole body)

(ii) squatting down

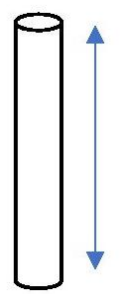

(iii) standing up (chanting the phrase: Long from the bottom to the top)

(iv) squatting down (chanting the phrase: Long from the top to the bottom)

(v) standing up (chanting the phrase: We can see the whole body. Yes, it's tall)

Figure 1 Gesture of 'tall' and its chants

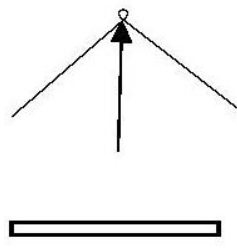

(i) pointing at the top of the figure (chanting the phrase: The top is far from the ground; we can't see the whole body)

(ii) pointing at the top of the figure (chanting the phrase: The top is far from the ground; we can't see the whole body. Yes, it's high)

Figure 2 Gesture of 'high' and its chants

\subsection{7 - Experiment}

The experiment to testify the effectiveness of embodied cognition approach was done in the following manner:

(i) 68 subjects (undergraduate students enrolled in introductory applied linguistic courses at Kindai university) were divided into the experimental group G1 ( $n=34)$ and the control group $\mathrm{G} 2(n=34)$ based on their TOEIC scores. ${ }^{3}$

(ii) Only G1 was given embodied cognitive experience-based teaching of meanings of high and tall. G1 performed two sets of gestures chanting the phrases five times. G2 was offered a conventional explanation (this traditional treatment includes (i) definitions of both 'high' and 'tall,' (ii) some example sentences, (iii) some basic usage notes).

(iii) Both groups took the same test in which all the participants were asked to choose one choice among (a) tall only, (b) high only, (c) both acceptable, for each of 20 items. The full point is 20 . An excerpt from the test is shown in (1) below.

(iv) The difference between the two groups was measured statistically by using T- test and analyzed.

${ }^{3}$ TOEIC is a popular English proficiency test in Japan; the score ranges from 10 to 990 points. 
HAMAMOTO, Hideki - Applying embodied cognition approaches to L2 learning. Para lá da tarefa: implicar os estudantes na aprendizagem de línguas estrangeiras no ensino superior.

Porto: FLUP, 2019, pp. 167-183 DOI: https://doi.org/10.21747/9789898969217/paraa9

(1) An excerpt from the test (translated into English from the original Japanese)

Can each item be modified by 'tall' or 'high' or both? Choose one answer to each.
a. wall (tall, high, both)
b. tower (tall, high, both)
c. tunnel (tall, high, both)
d. glass (tall, high, both)
e. mountain (tall, high, both)
f. hill (tall, high, both)
g. pyramid (tall, high, both)

\subsection{8 - Results}

Participants' global English proficiency was measured by using their TOIEC scores. Participants in $\mathrm{G} 1$ ( $n=34, M=505.6, S D=56.3)$ were slightly better in their scores than those in $\mathrm{G} 2(\mathrm{n}=34, \mathrm{M}=504.4, \mathrm{SD}=51.8)$; however, there was no significant difference between the two groups

(t $(66)=.09, p=.93, p>.05) . G 1$ and $G 2$ were on equal footing in terms of general English proficiency. This experiment inquired whether learners experiencing cognitive embodiment approach would exhibit any significant differences from those experiencing non-embodied instruction. On average, the participants in G1 recorded significantly greater points $(M=12.206, S D=1.591)$ than those in $G 2(M=10.735, S D=2.723)$. The result shows clearly that there was a significant difference statistically between the average scores of $\mathrm{G} 1$ and $\mathrm{G} 2$ ( $\left.\mathrm{t}(64)=2.72, \mathrm{p}=.008,{ }^{* *} \mathrm{p}<.01\right)$. This embodied-based instruction presented a considerably big sized effect (Cohen's d=.669). Embodied cognitive experience method, though simple and easy, worked very well for teaching meanings of these adjectives. In other words, the results suggest that learners succeeded in acquiring even partially a perceptual simulation of these adjectives in their mind, which led them out of the L2 zombie situation or at least close to the exit.

\section{2 - Experiment 2: semantics of English present perfect progressive}

Experiment 2 deals with semantics of the present perfect progressive tense, which Japanese learners of English consider difficult. When we hear a sentence like "my father has been washing his car since this morning," we naturally infer that the washing action is still going on. However, a sentence like "I've been running" responding to a question "why are looking so tired?" doesn't entail that running is still going on. The running process must have been ceased. This observation suggests that we must assume two 
HAMAMOTO, Hideki - Applying embodied cognition approaches to L2 learning. Para lá da tarefa: implicar os estudantes na aprendizagem de línguas estrangeiras no ensino superior. Porto: FLUP, 2019, pp. 167-183 DOI: https://doi.org/10.21747/9789898969217/paraa9

meanings for present perfect progressive. However, some grammar books published in Japan take continuation of a process as a necessary condition and even claim that the lack of it renders the sentence ungrammatical. Therefore, learners feel puzzled when they encounter some examples which obviously violate the rule which they assume to be true. This experiment was designed to respond to this elusive semantic issue and to measure the effectiveness of applying cognitive embodied experience to learning semantics of the present perfect progressive tense. According to Langacker (2001) and Radden \& Dirven (2007), the meaning of present perfect progressive tense is compositional, i.e., a combination of that of progressive and that of present perfect. Their explanation is summarized as in (2) below.

(2) Compositional analysis of present perfect progressive

(i) Progressive aspect focuses on durational phase of an activity and puts the end-point out of focus.

(ii) Present perfect aspect focuses on the present time and puts the event into indefinite past time.

(iii) Present perfect aspect requires an interpreter to search for current relevance of the past event to the present time. Current relevance may be either the continuation of the activity to the present moment or a resultative state which is caused by the activity.

(Langacker, 2001; Radden \& Dirven, 2007)

The above elucidation captures semantics of present perfect progressive precisely and compactly but is not easily understandable when one considers an aspectual feature of a sentence containing present perfect progressive. Reading (2) above is not considered as cognitive embodied experience. We need to translate the above criteria into more accessible framework. A possible solution is to have learners perform skits in which sentences with the present perfect progressive are used.

\subsection{1 - Procedure}

Here is the procedure for this experiment.

(i) 59 subjects (undergraduate students enrolled in Applied Linguistics courses at Kindai university) were divided into the experimental group $G 1(n=30)$ and the control group $\mathrm{G} 2(\mathrm{n}=29)$ based on their TOIEC scores. 
HAMAMOTO, Hideki - Applying embodied cognition approaches to L2 learning. Para lá da tarefa: implicar os estudantes na aprendizagem de línguas estrangeiras no ensino superior. Porto: FLUP, 2019, pp. 167-183 DOI: https://doi.org/10.21747/9789898969217/paraa9

(ii) Participants in G1 read a brief explanation of two usages of the present perfect progressive. They made a pair and performed two skits in which two distinguishable types of the present perfect progressive tense were used.

(iii) G2 was offered a conventional explanation, which encompassed (a) difference between present perfect and present perfect progressive, (b) the basic semantic feature of the present perfect progressive, i.e., description of an action which started in the past and continues up to the present moment, (c) two interpretations: ongoing action and recently completed action.

(iv) Both groups took the same test which measured their understanding of the meanings of present perfect progressive tense.

(iv) The difference between the two groups was measured statistically by using T- test and analyzed.

Participants in G1 read the following brief explanation of two usages of the present perfect progressive tense (the original in Japanese).

(3) Two usages of the present perfect progressive

(a) An action which started before and continues up to now

(b) Recently completed action

After reading the explanation, the participants in $\mathrm{G} 1$ made a pair and practiced saying and acting the following two skits. They changed the roles and kept practicing until they were able to act both roles naturally without looking at the scenario.

(4) Skit 1 (on-going usage)

A: I will count how long you can stand on one leg. Are you ready? Go!

$B$ : (start standing on one leg)

A: Ok, ten seconds.

B: (still standing on one leg) l've been standing on one leg for ten seconds.

Skit 2 (completed action usage)

A: You're breathing hard and all sweaty.

B: (panting, stooping, and wiping the sweat from his/her forehead)

I've been exercising.

(looking at A's hands) 
HAMAMOTO, Hideki - Applying embodied cognition approaches to L2 learning. Para lá da tarefa: implicar os estudantes na aprendizagem de línguas estrangeiras no ensino superior.

Porto: FLUP, 2019, pp. 167-183 DOI: https://doi.org/10.21747/9789898969217/paraa9

Your hands are dirty.

A: I've been gardening all this afternoon.

\subsection{2 - Experiment}

All the subjects ( $G 1$ and $G 2$ ) took the same test, which consisted of two parts. Question 1 asked them to classify each sentence with present perfect progressive into three cases. Question 2 asked for their grammatical judgement. Consider the test below.

(5) Test - present perfect progressive (12 points)

Question 1 Read the following and classify each of them into three cases: (i) the underlined process is still going on at this present moment; or (ii) the process has been ceased leaving current relevance to the present time; (iii) both cases above are possible. (10 points)

(a) You've been fighting again. I can tell that from your black eye.

(b) Look. He has been fighting for an hour on the ring.

(c) Look. The ground is white. It's been snowing.

(d) It's been snowing for three hours.

(e) Have you been crying? Your eyes are red.

(f) A: What have you been up to? B: I've been reading this book since this morning.

(g) You have been practicing the violin. I can tell this from your violin bruise.

(h) She has been repairing her camera since early this morning.

(i) He has been trying to get Sally on the phone. But his attempts are all in vain.

(j) Somebody has been sitting in my chair. And it is broken!

Question 2 Explain the difference in acceptability of (a) and (b). (2 points)

(a) ? My father has been washing his car and now he is in the living room drinking coffee.

(b) My father has been washing his car and his clothes are still wet.

\subsection{3 - Results}

Participants' global English proficiency was measured by using their TOIEC scores. Participants in $\mathrm{G1}(\mathrm{M}=504, \mathrm{SD}=79.4)$ were slightly lower in their scores than those in $\mathrm{G} 2$ $(M=506, S D=84.7)$; however, there was no significant difference between the two 
HAMAMOTO, Hideki - Applying embodied cognition approaches to L2 learning. Para lá da tarefa: implicar os estudantes na aprendizagem de línguas estrangeiras no ensino superior. Porto: FLUP, 2019, pp. 167-183 DOI: https://doi.org/10.21747/9789898969217/paraa9

groups $(\mathrm{t}(57)=-0.055, \mathrm{p}=.956, \mathrm{p}>.05) . \mathrm{G} 1$ and $\mathrm{G} 2$ were on equal footing in terms of the language level.

Consider the descriptive statistics and the results of $\mathrm{T}$ - test. The participants in $\mathrm{G} 1$ $(n=30)$ recorded greater points $(M=9.414, S D=1.24)$ than those in $G 2(n=29, M=8.714$, $\mathrm{SD}=1.27)$. The result shows that there was a significant difference statistically between the average scores of $\mathrm{G} 1$ and $\mathrm{G} 2$ ( $\left.\mathrm{t}(54)=2.102, \mathrm{p}=.0401,{ }^{*} \mathrm{p}<.05\right)$. It did present a medium sized effect (Cohen's $d=.567$ ). Therefore, this 'skit method' for teaching semantics of the present perfect progressive exhibits an immediate effect. The results suggest that this method was beneficial for guiding our learners towards the exit from the L2 zombie situation.

\section{3 - Discussion}

These experiments have exhibited favorable results for the cognitive embodiment approach.

As for experiment 1, performing the gestures illustrating the meanings of two adjectives helped participants choose the correct one to modify various objects. Since meanings of these adjectives are considered as qualia, learners cannot access them only by reading an explanation. Performing gestures afforded learners opportunities to experience a real feel for these adjectives.

As for experiment 2, acting the skits illustrating the compositional feature of English present perfect progressive allowed learners to notice subtle semantic differences involved in the construction. In both experiments, participants in G1 were encouraged to move their bodies. Some participants commented favorably on the effect of the skit method in experiment 2. They commented, "the skit method is very convincing," "the meaning of the tense has sunk into my mind." The statistical results and these comments support the hypothesis of motor-to-semantics effects, which assumes motor processes and comprehension processes are co-related (Gibbs, 2005). The participants in both $\mathrm{G} 1$ and G2 had quite extensive experience in studying English. In their English class, they learned some rules of the present perfect progressive, which were biased towards the ongoing process interpretation. Therefore, they needed to have a good opportunity which urged them to revise their understanding of this construction. This skit method was strong enough to have them change their understanding of the construction. The successful results of these two experiments support Gibbs' view that our body serves as a significant resource for people's understanding of many abstract concepts and the basic assumption that language is a product which results from our cognitions of bodily 
HAMAMOTO, Hideki - Applying embodied cognition approaches to L2 learning. Para lá da tarefa: implicar os estudantes na aprendizagem de línguas estrangeiras no ensino superior. Porto: FLUP, 2019, pp. 167-183 DOI: https://doi.org/10.21747/9789898969217/paraa9

experience. Embodied learning activities including the gestures and skits in the present study can offer intuitively simple way for learners to grasp subtle and elusive items such as space-related adjectives as well as a complex construction such as the present perfect progressive. However, we must admit that there was a drawback in these experiments. That is, a delayed test was not carried out in both experiments to measure the continuing effects of the cognitive embodiment instruction. Therefore, these cognitive embodiment approaches were effective at least immediately after the instruction was made. Admittedly, long-lasting effects should be experimentally confirmed, but the present results suggest that we are on the right track towards obtaining an effective remedy to save learners from the $\mathrm{L} 2$ zombie situation.

\section{4 - Conclusion}

We have two research questions. The first question is whether a cognitive embodiment approach is applicable to teaching and learning English. The second question is how we can render cognitive embodiment concepts accessible to learners. The answer to the first question is that cognitive embodiment is beneficial as far as our experiments are concerned. In relation to the second research question, attention should be paid to the fact that gestures representing meanings of 'high' and 'tall,' and skits representing semantics of the present perfect progressive tense are based upon the laborious semantic research. Instructors who plan to employ cognitive embodiment for their teaching must first consult cognitive science literature to explore studies of their interest. Secondly, they need to devise an effective method by which they can render their knowledge acceptable to learners through cognitive embodied experiences. In this respect, gestures and skits are not only methods available for L2 instruction (Suethanapornkul, 2014). With many more studies, the question of how and where embodiment approach plays an important role in L2 instruction may be answered more clearly.

\section{References}

Chalmers, D. (1996). The Conscious Mind: In Search of a Fundamental Theory. New York and Oxford: Oxford University Press.

Klir, G.J. \& Folger, T.A. (1988). Fuzzy Sets, Uncertainty, and Information. Englewood Cliffs, NJ, Prentice Hall. 
HAMAMOTO, Hideki - Applying embodied cognition approaches to L2 learning. Para lá da tarefa: implicar os estudantes na aprendizagem de línguas estrangeiras no ensino superior. Porto: FLUP, 2019, pp. 167-183 DOI: https://doi.org/10.21747/9789898969217/paraa9

Gibbs, R. W. (2005). Embodiment and cognitive science. Cambridge, UK: Cambridge University Press.

Hauk, O., Johnsrude, I., \& Pulvermüller, F. (2004). Somatotopic representation of action words in human motor and premotor cortex. Neuron, 41(2), 301-307.

Langacker, R. (1987). Foundation of Cognitive Grammar. Vol. I: Theoretical Prerequisites. Stanford CA: Stanford University Press.

Langacker, R. (2001). The English present tense. English Language and Linguistics, 5, 251-272.

Pecher, D., \& Zaawan, R. A. (2005). Grounding Cognition - the Role of Perception and Action in Memory, Language, and Thinking. Cambridge: Cambridge University Press.

Radden, G. \& Dirven, D. (2007). Cognitive English Grammar. Amsterdam: John Benjamins.

Smith, L. \& Gasser, M. (2005). The development of embodied cognition: Six lessens from babies. Artificial Life, 11, 13-29.

Suethanapornkul, S. (2014). Embodied Experiences in Second Language Learning of English Modal Verbs. Proceedings of the 2012 Second Language Research Forum, 181-192.

Taylor, J.R. (1992). A problem with synonyms (and a way to a solution). South African Journal of Linguistics, 10 (2), 99-104.

Taylor, J.R. (2002). Cognitive Grammar. New York and Oxford: Oxford University Press.

Tyler, A. (2012). Cognitive Linguistics and Second Language Learning. London: Routledge.

Tyler, A. \& Evans, V. (2001). Reconsidering prepositional polysemy networks: The case of over. Language, 77(4), 726-765.

Zwaan, R. A., Starfield, R. A. \& Yaxley, R. H. (2002). Language comprehenders mentally represent the shapes of objects. Psychological Science, 13, 168-171. 
HAMAMOTO, Hideki - Applying embodied cognition approaches to L2 learning. Para lá da tarefa: implicar os estudantes na aprendizagem de línguas estrangeiras no ensino superior.

Porto: FLUP, 2019, pp. 167-183 DOI: https://doi.org/10.21747/9789898969217/paraa9

\section{Appendix Tall/High preference scores of forty-one items}

\begin{tabular}{|c|c|c|c|c|c|c|c|}
\hline $\begin{array}{l}\text { num } \\
\text { ber }\end{array}$ & item & tall ave. & SD & high ave. & SD & difference & \\
\hline 1 & girl & 1.12 & 0.322 & 6.09 & 1.222 & -5.0 & -23.277 \\
\hline 2 & glass & 1.35 & 0.681 & 5.50 & 1.460 & -4.1 & -15.227 \\
\hline 3 & giraffe & 1.35 & 0.762 & 5.50 & 1.440 & -4.1 & -15.058 \\
\hline 4 & fir tree & 1.35 & 0.478 & 4.21 & 1.728 & -2.9 & -9.413 \\
\hline 5 & building & 1.41 & 0.732 & 2.94 & 1.714 & -1.5 & -4.854 \\
\hline 6 & cocktail-glass & 1.50 & 0.606 & 5.03 & 1.424 & -3.5 & -13.489 \\
\hline 7 & factory chimney & 1.76 & 1.002 & 3.38 & 1.925 & -1.6 & -4.410 \\
\hline 8 & skyscraper & 1.79 & 1.255 & 2.79 & 1.623 & -1.0 & -2.884 \\
\hline 9 & pillar & 1.85 & 1.240 & 3.29 & 1.340 & -1.4 & -4.670 \\
\hline 10 & spire & 1.91 & 1.314 & 2.68 & 1.408 & -0.8 & -2.348 \\
\hline 11 & willow & 1.91 & 1.222 & 4.12 & 1.659 & -2.2 & -6.335 \\
\hline 12 & telegraph pole & 2.00 & 1.283 & 2.94 & 1.454 & -0.9 & -2.871 \\
\hline 13 & ostrich & 2.03 & 1.424 & 5.26 & 1.290 & -3.2 & -9.959 \\
\hline 14 & bookcase & 2.06 & 1.136 & 2.94 & 1.392 & -0.9 & -2.905 \\
\hline 15 & tower & 2.24 & 1.307 & 2.00 & 1.111 & 0.2 & 0.811 \\
\hline 16 & apartment house & 2.24 & 1.262 & 4.24 & 1.783 & -2.0 & -5.417 \\
\hline 17 & grass & 2.44 & 1.785 & 2.50 & 1.480 & -0.1 & -0.150 \\
\hline 18 & chest of drawers & 2.71 & 1.824 & 3.44 & 1.718 & -0.7 & -1.736 \\
\hline 19 & pyramid & 2.74 & 1.614 & 3.06 & 1.697 & -0.3 & -0.817 \\
\hline 20 & box & 2.85 & 1.784 & 4.29 & 1.525 & -1.4 & -3.632 \\
\hline 21 & church & 2.88 & 1.891 & 4.00 & 1.863 & -1.1 & -2.491 \\
\hline 22 & window & 3.12 & 1.659 & 2.29 & 1.563 & 0.8 & 2.138 \\
\hline 23 & wardrobe & 3.15 & 1.896 & 3.21 & 1.491 & -0.1 & -0.144 \\
\hline 24 & horse & 3.15 & 1.942 & 4.21 & 1.952 & -1.1 & -2.275 \\
\hline 25 & house & 3.21 & 2.011 & 4.59 & 1.665 & -1.4 & -3.132 \\
\hline 26 & mountain & 3.44 & 1.752 & 1.50 & 0.697 & 1.9 & 6.091 \\
\hline 27 & dog & 3.47 & 2.076 & 5.94 & 1.162 & -2.5 & -6.145 \\
\hline 28 & shadow & 3.59 & 2.315 & 5.09 & 1.869 & -1.5 & -2.983 \\
\hline 29 & bridge & 3.62 & 1.766 & 1.91 & 1.039 & 1.7 & 4.925 \\
\hline 30 & door & 3.88 & 1.843 & 3.35 & 2.013 & 0.5 & 1.148 \\
\hline 31 & dome & 4.21 & 1.906 & 1.97 & 1.361 & 2.2 & 5.646 \\
\hline 32 & table & 4.26 & 1.787 & 2.65 & 1.432 & 1.6 & 4.178 \\
\hline 33 & wall & 4.82 & 1.671 & 2.03 & 1.543 & 2.8 & 7.267 \\
\hline 34 & room & 4.97 & 1.581 & 4.35 & 1.983 & 0.6 & 1.441 \\
\hline 35 & hill & 5.12 & 1.745 & 2.94 & 1.748 & 2.2 & 5.213 \\
\hline 36 & precipice & 5.18 & 1.671 & 1.85 & 1.263 & 3.3 & 9.386 \\
\hline 37 & tunnel & 5.26 & 1.335 & 3.24 & 1.926 & 2.0 & 5.123 \\
\hline 38 & ceiling & 5.38 & 1.237 & 1.12 & 0.322 & 4.3 & 19.737 \\
\hline 39 & cave & 5.44 & 1.376 & 3.15 & 1.768 & 2.3 & 6.058 \\
\hline 40 & cloud & 6.09 & 1.292 & 1.94 & 1.662 & 4.1 & 11.657 \\
\hline 41 & hair & 6.18 & 1.224 & 5.26 & 1.771 & 0.9 & 2.506 \\
\hline
\end{tabular}

